\title{
Development of Integrated Organic Agricultural Agribusiness at D'jamuran Pekanbaru Student Business
}

\author{
Isna Rahma Dinia), Hapsoh, Rachmad Saputra, Desita Salbiah, and Sri Yoseva \\ Jurusan Agroteknologi, Fakultas Pertanian, Universitas Riau, Pekanbaru, Indonesia \\ a)Corresponding Author : isna.rahmadini@lecturer.unri.ac.id
}

\begin{abstract}
Oyster mushroom is a mushroom that is quite in demand by the people of Pekanbaru City. One of the oyster mushroom producers in Pekanbaru is a young entrepreneur named Solihin who is a student of the Department of Agrotechnology, Riau University. Oyster mushroom production ranges from $15-40 \mathrm{~kg} /$ day. The high production of mushrooms is supported by the number of baglogs owned by Solihin. After being used to produce mushrooms, this baglog will of course become waste. The high content of organic matter in baglog waste makes baglog waste a potential medium for the development of African Night Crawlers (ANC) worms. Furthermore, the remaining growth media for this worm can be used as vermicompost fertilizer. Therefore, the purpose of this service is to provide assistance in the cultivation of ANC worms to entrepreneurs who are partners in this service. Based on the results of the service carried out, partners have succeeded in developing by-products other than oyster mushrooms into useful and selling products which can certainly increase partners' income. In addition, partners are also developing fish farming as a continuation of the use of ANC worms as fish feed. This is because ANC worms are a high source of protein for fish feed. Through this service activity, the development of integrated agricultural agribusiness has been realized.
\end{abstract}

Keywords: Mushroom baglog waste, ANC worms,,fish feed, integrated agriculture.

\section{INTRODUCTION}

Oyster mushroom (Pleurotus ostraetus) is one of the foods that are in great demand by the people of Pekanbaru City today. Various processed foods made from oyster mushrooms such as dragon feet, mushroom nuggets, mushroom ice cream (Fivintari et al., 2021), crispy mushrooms, risoles cake filling (Qodarin et al., 2021), oyster mushroom rending, oyster saus oyster mushrooms, and barbecue-flavored mushroom chips (Widodo et al., 2016). The demand for white oyster mushrooms from 2014 in Pekanbaru City reached 800-5,000 kg per month. Based on data from the Pekanbaru City Agriculture Service in 2014, there were 10 oyster mushroom cultivators who are currently still running the white oyster mushroom business (Tety et al., 2017). One of the mushroom cultivators who developed an oyster mushroom business in Pekanbaru City is a student of the Department of Agrotechnology, Faculty of Agriculture, named Solihin, who is an entrepreneur in cultivating mushrooms as a side income source during his studies. The mushroom cultivation business carried out by Solihin began in 2018 with the business name D'Jamuran Pekanbaru. Solihin also has two productive mushroom houses so that in a month it can generate an average monthly profit of 3 million rupiah from the sale of fresh white oyster mushrooms during 2020.

The increase in the mushroom cultivation business carried out, of course, will cause problems, one of which is the handling of the remaining mushroom media waste (baglog). The more mushroom cultivation business increases, the more the amount of baglog waste that will be generated will increase. So far, the remaining baglog produced by Solihin is sold at relatively low prices to worm farmers in Pekanbaru. In fact, if the cultivation of worms can be carried out directly by Solihin by utilizing his baglog waste, then of course it can increase the income generated by Solihin as a by-product of this oyster mushroom cultivation activity. 
One of the uses of mushroom baglog waste is to become a medium for worm cultivation. Several assistance activities for the use of baglog waste for worm cultivation have been carried out by Kurniati (2017) and Yuniarti et al. (2020). Based on the results of the analysis, oyster mushroom baglog waste contains water content of 37.2\%, $0.93 \%$ Nitrogen, $2.07 \%$ Phosphorus, 8.5\% Potassium, and a C/N ratio of 37.19 (Bellapama et al., 2015). The high content of organic matter in mushroom baglog waste can certainly provide potential as a medium for worm development. In addition, the use of baglog for worm cultivation can meet the high demand for worms. According to (Aziz, 2015), the need for earthworms can reach more than one hundred tons per month, while many people still rely on catching from natural habitats such as rice fields and swamps to meet their hatchery needs. This of course can threaten the population in nature, which will have an impact on disrupting the natural decomposition process of the soil. Therefore, the use of baglog waste as a medium for worm cultivation has great potential in overcoming the needs of worms. In addition to being used for worm cultivation, Adinurani \& Rahayu (2021) have assisted in the utilization of baglog waste to make compost and make briquettes (Irawati et al., 2017).

However, not only earthworms can be developed by utilizing baglog waste, but there is another type of worm called the African Night Crawler (ANC) worm. According to Sunarjo \& Yuniarti (2017), ANC worms can also be used for medicines such as typhoid medicine and as an energy drink. In addition to medicine, worm meal can be used as a substitute for fish meal in the manufacture of fish pellets. The high protein content in worms makes worms potential to be developed as fish pellets. Therefore, in this service, fish farming is also developed around the mushroom and worm cultivation sites.

The development of baglog waste-based products for the production of ANC worms and tilapia cultivation will support the realization of integrated agriculture. It is hoped that through community service activities with this entrepreneurship program, it can encourage partners as oyster mushroom cultivators to develop by-products other than oyster mushrooms that are of sale value so that they will be able to increase their income.

\section{METHOD}

This service will be carried out in a mushroom cultivation business called D'jamuran owned by an entrepreneur named Solihin who is a partner of service activities.

The design of service activities that have been carried out consists of several stages by applying 4 approach models so that the implementation of service runs and reaches the target, which are as follows:

1. Participatory Rural Appraisal (PRA) model. This pattern involves all parties (actors) in the decision-making process which directly affects those who have an impact on development.

2. Participatory Technology Development model that utilizes appropriate technology based on science and cultural wisdom.

3. Persuasive, namely an approach that is an appeal and support without an element of coercion for the community to play an active role in this activity.

4. Educational, namely the approach to socialization, training and assistance as a means of transferring knowledge and education for community empowerment.

Some indicators of the achievement of service activity programs include:

1. Increasing partners' side business results through the use of baglog waste

2. The realization of entrepreneurship with the application of science and technology

3. Increase partner income outside of oyster mushroom cultivation

4. The creation of independent entrepreneurs and will become partners in the partnership scheme in the following year 


\section{RESULTS And DISCUSSION}

The oyster mushroom cultivation business built by this target partner is called "D' Mushroom". This business was established on October 19, 2018 on an area of $300 \mathrm{~m} 2$ which is located at $\mathrm{Jl}$. Elang Sakti, Simpang Baru Village, Tampan District, Pekanbaru City. The number of kumbung owned by partners is 2 kumbung, while the number of baglogs owned is 11,000 consisting of 6,000 baglogs that are still in mushroom production, 2,000 baglogs that have just been inoculated with mushrooms and have not been produced, and 3,000 baglogs that have become waste. The mushroom cultivation conditions owned by partners can be seen in Figure 1.

Mushroom harvesting is done every day where the average daily production is $15-40 \mathrm{~kg}$. The income generated by Solihin from the sale of mushrooms is around Rp. 15-25 million. This income will be paid for mushroom harvesters, buying baglogs for mushroom cultivation, and other operational costs. The price of one baglog is Rp. 3,500. One baglog can produce as much as $300-$ $600 \mathrm{~g}$ in a harvest period of 90-100 days (3 months). The selling price of mushrooms after harvesting is Rp. 25,000 , - /kg. This means that one baglog can produce as much as IDR 7,500 IDR 15,000 / baglog and when multiplied by the total baglog currently owned (6,000 baglogs), the total range of Solihin's income from oyster mushroom cultivation for a period of 3 months is 4590 million. If you deduct the purchase of baglog (Rp 3,500/baglog) and the cost of harvesting wages and other operations (around Rp. 10 million/3 months), the net income earned is around Rp. 14-59 million/3 months.

Although the income of partners (Solihin) is quite a lot, there are business opportunities that can be additional income for partners. One of the business opportunities that can be done is the cultivation of ANC worms based on mushroom baglog waste. Mushroom baglog waste that can no longer produce can be used as a medium for worm development. Utilization of baglog mushroom waste for worm cultivation has been carried out by Nurwati (2011) who reported that there was an increase in the biomass of Pheretima sp. on the composition of baglog waste: albasia wood saw waste $=1: 1$. The high content of organic matter in baglog waste can be a source for the development of ANC worms. Baglog waste that has the potential to be used as a medium for worms can be seen in Figure 2.

Worm cultivation is carried out by utilizing baglog waste that is no longer producing. Worm cultivation activities begin with building a house to cultivate worms. Through this service activity, an ANC worm cultivation house has been built with a size of $5 \times 8$ meters using a light steel building covered with plastic-coated paranet and covered with a tin roof covered with thatched roof. Inside the cultivation house, a worm rack measuring $1.2 \times 7$ meters was built with 3-level shelves with 3 rows of shelves. The worm rack can accommodate $800-1,500 \mathrm{~kg}$ of worms once harvested / 3 months.

ANC worm cultivation media uses used baglog waste that is no longer productive. Prior to use, the waste is crushed to a fine powder and sieved using a sieve net and then spread into a worm rack. The stocking of ANC worm seeds was carried out after all the cultivation media became moist, the seeds used for stocking were juveniles of 20-30 days of $30 \mathrm{~kg}$ of seeds. During cultivation, the worms are given food in the form of leftover pieces of mushrooms and mushrooms that are damaged by mushroom harvests. Feeding is done every day where the need to eat worms with seeds as much as $30 \mathrm{~kg}$ as much as $6-10 \mathrm{~kg}$ of mushroom pieces waste every day. The condition of the mushroom cultivation media must be in a humid condition so that it must be sprayed onto the worm cultivation media. Next, the sorting process is carried out by selecting adult worms or large ones aged 20-60 days to be moved to a shelf containing new media with the aim of maintaining the loading capacity of the media so that it is sufficient for worm feeding and so that the worms can develop properly. The process of harvesting worms is carried out after the worms are 80-90 days old after stocking, with a stocking of $30 \mathrm{~kg}$ of worm seeds will produce a harvest of $90-150 \mathrm{~kg}$ of worms in 3 months of cultivation. The selling price of ANC worms in Pekanbaru is IDR $40,000-60,000 / \mathrm{kg}$. So, the side income that will be generated by partners from 
worm cultivation is around Rp. 5,000,000 - Rp. 9,000,000,-. ANC worm cultivation owned by partners through entrepreneurship programs can be seen in Figure 3.

The ANC worms produced from baglog mushroom waste are not only sold directly in the form of fresh worms. However, it can also be developed to be used as worm flour as a raw material for fish feed. Through this service, a fish farming business was also developed as a follow-up to the use of ANC worms as raw material for fish feed. The use of ANC worms for feed is caused because ANC worms have a fairly high protein content. According to Sunarjo \& Yuniarti (2017), the high content of essential amino acids in worm flour will make fish growth faster and feeding with worm meal extract will make fish much healthier. The establishment of this fish farming business will certainly be able to increase income for partners and the existence of this fish cultivation will later be able to realize integrated agriculture based on oyster mushroom cultivation. The fish farming pond that has been built in this service activity can be seen in Figure 4.

This entrepreneurship program activity is also supported for the development of a fish farming business by making a fish pond located next to the kumbung mushroom. The area of the fish pond is $10 \times 11 \mathrm{~m}$ with a stocking density of 10,000 fish. The type of fish that is cultivated is tilapia. This is because tilapia is a fish that has high economic value in Pekanbaru so that later it is very easy to market. If the tilapia cultivation is successful, it is estimated that the income received by partners is $\mathrm{Rp} .37,500,000$, which is obtained if the fish harvested is about 1.5 tons with the selling price of fish per kilo of Rp. 25,000.

This service activity provides a great opportunity for partners to further develop side businesses other than oyster mushroom cultivation. If ANC worm farming and fish farming continue to be carried out, the partners' income will be much higher than before. Therefore, several levels of achievement of the targets of this program include:

1. Increasing partners' side business results through the utilization of mushroom baglog waste;

2. The realization of independent entrepreneurship with the application of science and technology;

3. Increase the income of partners outside of the oyster mushroom cultivation business;

4. The realization of independent entrepreneurs as partners in the partnership scheme in the following year.

Based on the results above, the implementation of service activities for partners through entrepreneurship programs has been carried out properly and as planned.

\section{CONCLUSIONS And RECOMMENDATIONS}

From the results of the service carried out, it can be concluded that the target partners have succeeded in developing by-products other than oyster mushrooms such as African Night Crawlers (ANC) worm cultivation and tilapia cultivation. Through this side business it has helped in increasing partners' income. In addition to increasing income, there is also an increase and development of the potential for independent entrepreneurs based on science and technology who developed from the mushroom business, and the formation of an integrated oyster mushroom farming center in Pekanbaru. Suggestions that can be given from the results of this service activity are so that partners can further develop by-products of mushroom cultivation by utilizing baglog waste for organic fertilizer, fuel and animal feed.

\section{ACKNOWLEDGMENTS}

Thank you to LPPM Riau University through the Entrepreneurship Service Program in 2021 which has funded this service activity with Contract No: 529/UN19.5.1.3/PT.01.03/2021.

\section{REFERENCES}

Adinurani, Praptiningsih Gamawati, Rahayu, S. (2021). Penanganan Limbah Baglog Jamur Tiram (Pleurotus osteatus) di Desa Bodag Kecamatan Kare Kabupaten Madiun. Dinamisia: Jurnal Pengabdian Kepada Masyarakat, 5(1), 206-213. 
Aziz, A. (2015). Budidaya Cacing Tanah Unggul ala Adam Cacing. Jakarta: AgroMedia Pustaka.

Bellapama, I. A., Hendarto, K., \& Widyastuti, R. A. D. (2015). Pengaruh pemupukan organik limbah baglog jamur dan pemupukan takaran NPK terhadap pertumbuhan dan produksi pakchoy (Brassica chinensis L.). Jurnal Agrotek Tropika, 3(3), 327:331.

Fivintari, F. R., Wulandari, R., \& Wijaya, O. (2021). Pendampingan Pengembangan Usaha Agribisnis Jamur Tiram sebagai Upaya Peningkatan Pendapatan Keluarga. Community Empowerment, 6(4), 641-648.

Irawati, D., Pradipta, N. N., \& Sutapa, J. P. G. (2017). Usaha Pemanfaatan Limbah Budi Daya Jamur sebagai Bahan Baku Pembuatan Briket di Kelompok Tani Jamur Sedyo Lestari Desa Argosari, Kecamatan Sedayu, Bantul. Indonesian Journal of Community Engagement, 2(02), 175-188.

Kurniati, E. (2017). THE USEFULL OF WASTE OF MUSHROOMS FOR WORM SOIL PRODUCTION. Journal of Innovation and Applied Technology, 3(1), 429-432.

Nurwati, S. R. (2011). Pemanfaatan limbah baglog jamur sebagai media budidaya cacing Pheretima sp. Universitas Gadjah Mada. http://etd.repository.ugm.ac.id/home/detail_pencarian/51472

Qodarin, M., Rodiaminullah, Faqih, F., Firmansyah, S., Rofiqoh, R., \& Anwar, K. (2021). PENDAMPINGAN PENGEMBANGBIAKAN USAHA JAMUR TIRAM MASYARAKAT DESA LONKEBUN Kerjasama dengan Yayasan Nailun Najah Desa Lonkebun Kecamatan Ketapang Kabupaten Sampang. Al-Khidmah: Jurnal Pengabdian Kepada Masyarakat, 1(2), 96-106.

Sunarjo, S., \& Yuniarti, S. (2017). Pemanfaatan sayur buangan untuk pakan cacing African Night Crawler (ANC) sebagai bahan pembuat pellet. Abdimas: Jurnal Pengabdian Masyarakat Universitas Merdeka Malang, 2(1), 43-49.

Tety, E., \& Cintami, Rachmawaty Sri, Yusmini, Y. (2017). Analisis Usahatani Jamur Tiram Putih (Pleurotus ostreatus) Di Kota Pekanbaru. PEKBIS (Jurnal Pendidikan Ekonomi Dan Bisnis), 9(1), 1-10.

Widodo, W., Kamardiani, D. R., \& Aini, L. N. (2016). Kewirausahaan Jamur Tiram Di Pondok Pesantren. BERDIKARI: Jurnal Inovasi Dan Penerapan Ipteks, 4(1), 23-30.

Yuniarti, S., Sunarjo, S., \& Sedyowati, L. (2020). Budidaya Cacing Lumbricus Rubellus dengan Media Limbah Jamur sebagai Bahan Dasar Kosmetik dan Obat-Obatan. Abdimas: Jurnal Pengabdian Masyarakat Universitas Merdeka Malang, 5(2), 93-104. 


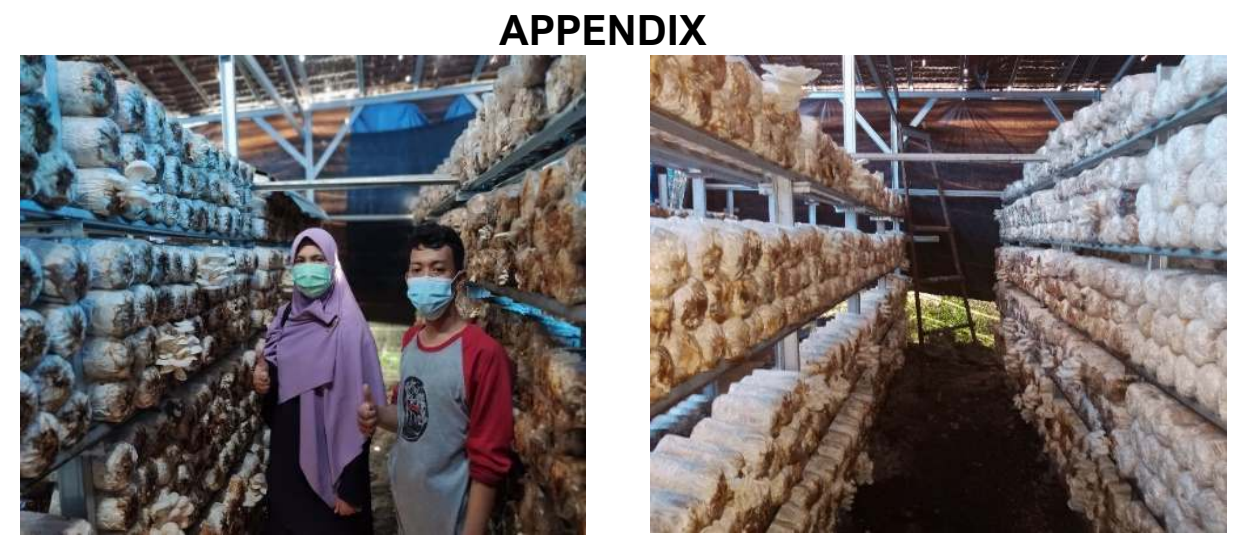

Figure 1. The condition of mushroom cultivation in kumbung owned by entrepreneurship program service partners
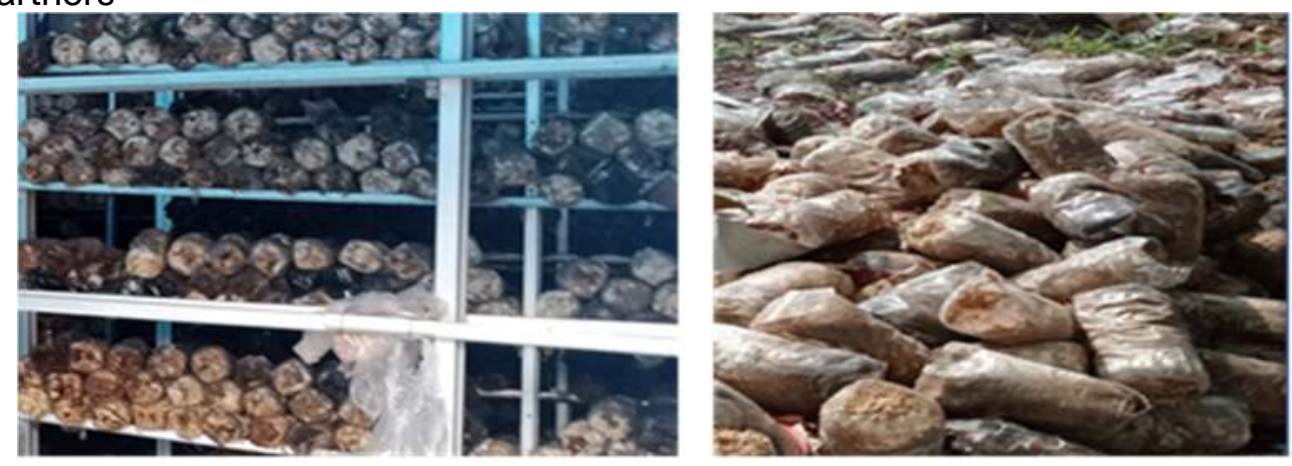

Figure 2. Mushroom baglog waste that has the potential to be a growth medium for ANC worms
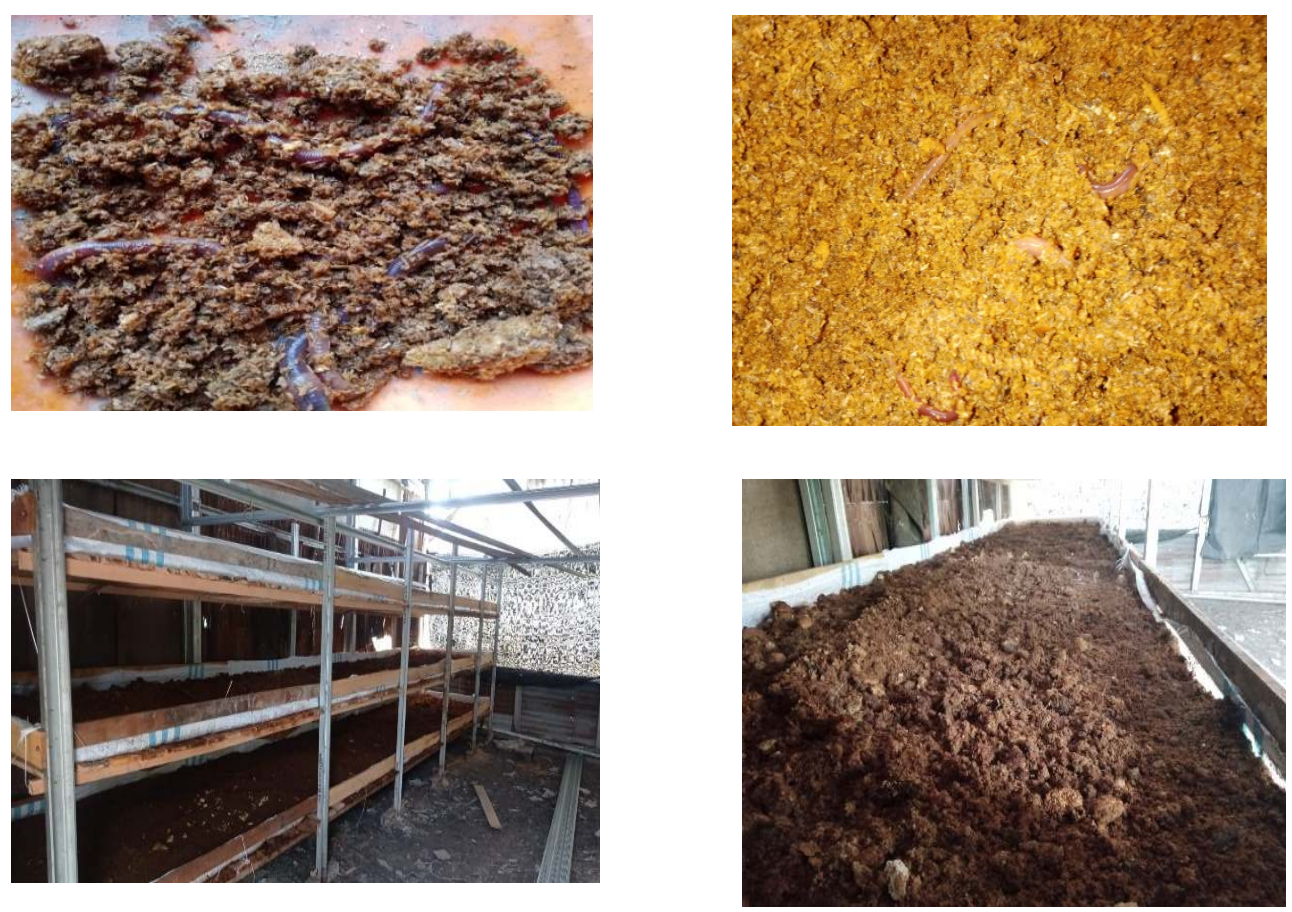

Figure 3. Cultivation of ANC worms by utilizing baglog mushroom waste as a medium for the development of ANC worms 

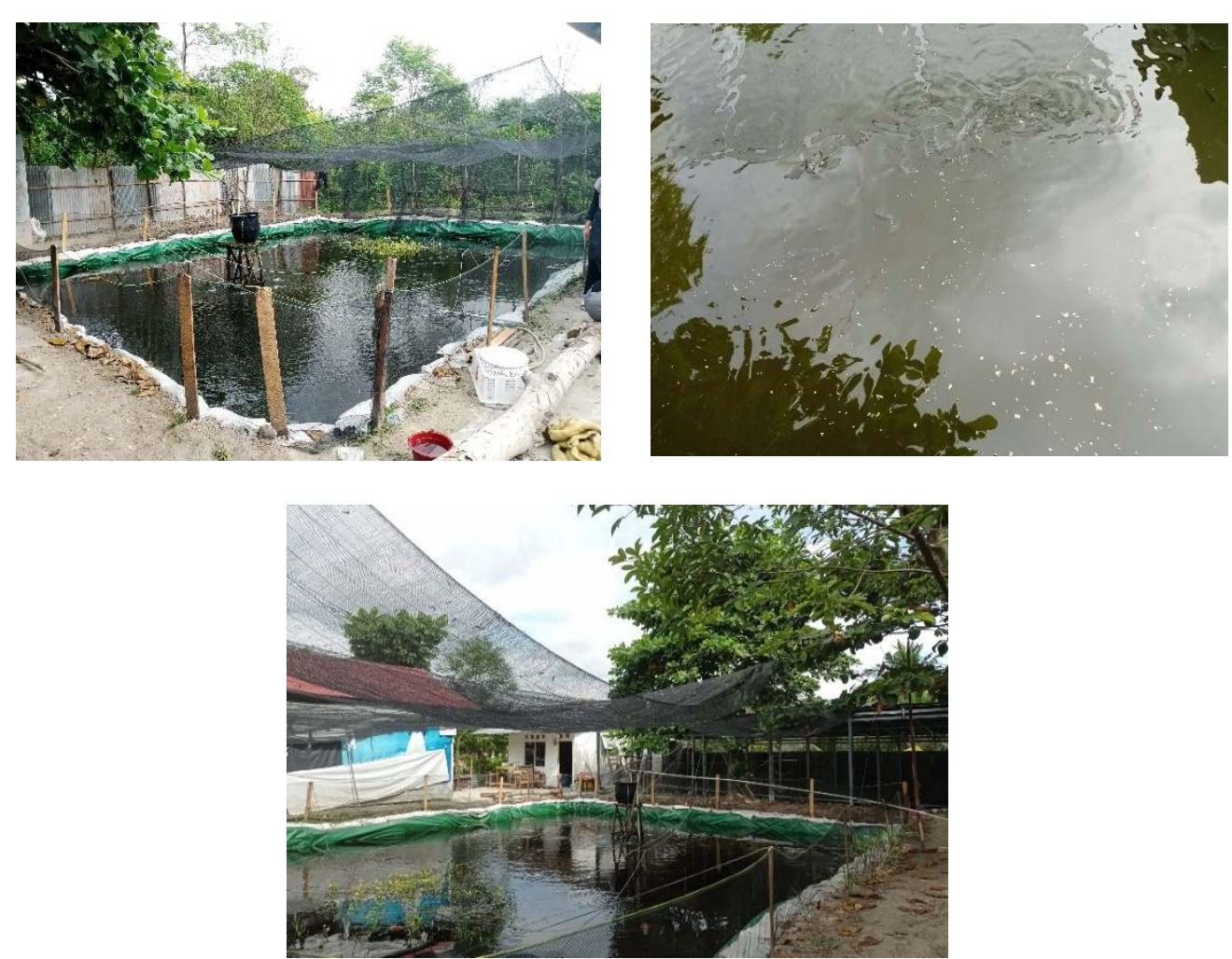

Figure 4. Tilapia cultivation in ponds through entrepreneurship program service activities to support integrated agriculture 